\title{
Complementary ways of meeting the world's protein need
}

\author{
By N. W. Pirie, Rothamsted Experimental Station, Harpenden, Herts
}

Before considering the various possible protein sources, we must make some sort of estimate of the possible protein need by-say-the end of the century. That estimate controls the amount of effort we should put into work on protein supplies and the degree of novelty that we should envisage. The estimate depends on the number of people to be fed and the amount of protein that each needs. Both quantities are uncertain: the first because it must be guessed, the second because it is hotly disputed.

At present our numbers are increasing at a rate that would double the population of the world in about 30 years. This rate cannot continue indefinitely; the more fecund parts of the world will probably settle down and achieve static or slowly increasing populations. With modern methods of contraception, it should, in principle be easier than in the past to achieve population stability. But it is important to remember that no method of contraception will be used effectively until people understand the basic principles of biology - this understanding will greatly increase the survival rate of those children that are born in spite of contraception. Consequently the first result of an effective campaign is likely to be an increase in the population. It would be foolish therefore not to envisage the possibility that we may have to feed 7 or $8 \mathrm{G}$ people by the end of the century. It would be even more foolish to rely on wars and epidemics to relieve us of a catering problem.

Purely biochemical and physiological considerations should specify how much protein each person needs. Communities, or individuals, that apparently eat as little as $40 \mathrm{~g}$ of protein a day may show no blatant signs of malnutrition, whereas those that apparently eat $\mathrm{I} 00 \mathrm{~g}$ may show no signs of plethora. Energy intake varies much less. The question is: would the first communities fare better on more protein or the second on less? A naive approach is to measure how much protein an individual needs in order to be in nitrogen balance. Obviously, someone not in balance is getting too little protein and will go on being depleted until an equilibrium is established at which metabolism is depressed so much that it matches intake. But it is unwarrantable to assume that as soon as the balance is struck, say at about $4^{\circ} \mathrm{g}$ protein per person per day, nutrition is adequate. Furthermore, if the average protein consumption in a community is $40 \mathrm{~g}$ a day, half get less than this. Communities vary in the extent to which food is evenly distributed. But there are few communities in which those most in need of protein-children and pregnant or lactating women-get preferential treatment. Foods rich in protein are usually the most highly esteemed parts of the diet and, through custom and selfishness, men tend to to get more than their share of them. It will be necessary to supply much more than the minimum amount of protein to ensure that everyone gets that minimum.

The ideal is easily stated: a person is not getting enough protein when well-being is increased by eating more protein. The ideal is easy to state but less easy to define 
or measure. With domestic animals we know what we want-rapid growth, a certain bodily conformation, a large milk yield, or abundant eggs. Although children grow much more slowly than domestic animals, their growth rate is a good index of the amount of protein in the diet. There is no evidence that rapid growth is desirable; some experiments on animals even suggest that it shortens the ultimate expectation of life. Life-tables do not however suggest that the non-obese members of well-fed communities have suffered.

We tend to accept the haemoglobin, plasma protein, and amino acid values found in the blood of the well-fed as the norm even when their bodily fat and blood cholesterol are regarded with dismay. This marks the beginnings of an attempt at physiological standards of good nutrition. The respiratory function of haemoglobin is well understood and there are measurable disadvantages in having too little of it; this is also true of plasma proteins such as the antibodies. There is less certainty about the advantage of maintaining specified concentrations of albumin and amino acids in the blood. These are presumably metabolites on their way to the sites where they will be used: Neale (1967) records the dramatic improvement in a patient given intravenously $25 \mathrm{~g}$ of albumin daily. Are there any advantages in maintaining such concentrations that much of the circulating material gets used simply as fuel? This is wasteful according to those who regard nitrogen balance measurements as a sufficient index of the adequacy of protein supplies. But 'waste' may be a concomitant of desirable effects. According to the 'euphoristic theory' of the function of glutathione, its presence, even when not used, is advantageous: some processes may proceed more effectively when protein and amino acids are always plentiful.

The evidence is suggestive rather than positive. Lawes \& Gilbert $(1852,1866)$ disproved Liebig's contention that muscular work involved protein metabolism; Liebig confused the structure of the muscular machine with its fuel. They cautiously added that there could be increased nitrogen metabolism when an animal was overtaxed or ' $\ldots$ in the human body, when under excitement or excessive mental exercise'. Though work does not increase nitrogen excretion, the impulse to work depends on the amount of protein in the diet. Children become more active when given more than the minimum requirement of protein, primates in the bettermanaged zoos are livelier now that they get diets containing $25-35 \%$ protein, and the performance of trained workers improved when they were given $I \cdot I$ rather than I $\mathrm{g}$ of protein per $\mathrm{kg}$ body-weight (FAO/WHO, I965).

There is general agreement that malnourishment in infancy, particularly protein deficiency, restricts brain development. It may also lead to impaired intellectual development, though this does not necessarily follow for there is little correlation between brain size and intellectual capacity. The early work on animals, mainly done in the USSR by pupils of Pavlov (surveyed by Brožek, 1962), is not easy to interpret because irritability characterizes human cases of kwashiorkor and it could be interpreted as enterprise or inquisitiveness in a laboratory animal. There is however evidence (e.g. Chow \& Blackwell, 1968) that the offspring of rats on restricted (in energy as well as protein) diets developed the usual reflexes later than the controls and never learnt to run mazes so efficiently. There are abnormalities in structure 
and co-ordination in pups from protein-deficient bitches and these are intensified when the pups are themselves weaned on protein-deficient diets (Stewart \& Platt, I968).

The death rate between $\mathrm{I}$ and 5 years of age is strongly correlated with protein deficiency. Admittedly, protein deficiency is commonest in countries with poor hygiene; infections are the recorded cause of most of these deaths. A suspicion remains that the protein-deficient have less resistance to bacterial infection. Animal experiments supporting this suspicion are reviewed by Dubos (1965). This is one aspect of well-being. Wound-healing is another. Hospital patients suffer less from the 'disuse syndrome' if, by culinary skill, they can be persuaded to eat $150 \mathrm{~g}$ of protein a day (Stevenson, 1946). There is evidence that dividing cells in the mucous membrane of the mouth, which is a site of regular mild wounding, are abnormally scarce in protein deficiency (Squires, I966). The gut also is subject to abrasion; it would be useful to know whether the great variations in 'normal' structure of the villi in people in different parts of the world (Creamer, 1967 ) and in different animals (Hofmann, 1968) arise because of diminished regeneration in protein deficiency.

No one would wish, casually, to increase the difficulties of countries with a food shortage by urging on them inflated nutritional standards; they should not, on the other hand, be encouraged to live in a 'fool's paradise', and much of the money they now spend goes on prestige projects of more debateable value than improved nutrition. When we consider the diets actually eaten by the more productive members of the community, including members of official committees that give niggardly trophological advice to others, it seems reasonable to think that lack of protein makes many members of apparently well-fed communities less healthy and responsive than they could be. It is possible that the average amount of protein eaten should be as great as $100 \mathrm{~g}$ a day. This opinion is shared by those who organize the US space programme; astronauts, the most up-to-date élite group, get $\mathrm{r} 20 \mathrm{~g}$.

Infants do not need $100 \mathrm{~g}$ of protein a day. But, in regions where poor hygiene causes widespread infection and infestation, adolescents and adults probably need more. If $7 \mathrm{G}$ people average $100 \mathrm{~g}$ a day, $256 \mathrm{M}$ tons of protein will be eaten in a year. The world total of protein, at the retail level, is $90 \mathrm{M}$ tons (FAO, I964), and the Protein Advisory Group concluded in 1966 that the world deficit was $20 \mathrm{M}$ tons even on its rather ungenerous estimate that individual needs ranged, according to age distribution and climate in different countries, from $40-52 \mathrm{~g}$ a day. We seem therefore to have a formidable problem now, and an even more formidable one is impending.

The percentage of protein in a day's food is nearly as important as the amount eaten in a day. Thus, someone doing very heavy work needs $4000 \mathrm{kcal}$ ( $17 \mathrm{M}$ joules) a day and so could, in principle, get $100 \mathrm{~g}$ of protein by eating the $1000 \mathrm{~g}$ of cereal, containing $9-1 \mathrm{I} \%$ of protein, that would provide that amount of energy. Sedentary people would get grossly fat if they tried to meet their protein needs in this way; unless some of their food contains $20 \%$ or more protein (on the dry matter) they are condemned to a low-protein diet. The recent increases in cereal yields in such countries as India, Mexico and the Philippines are extremely valuable because, in 
many parts of the world, hunger (i.e. energy shortage) is as great a problem as protein shortage so that much of what protein there is, has to be used by the body merely as fuel. Furthermore, cereals supply, and will probably continue to supply, between half and a third of our protein. Cereals have been found with enhanced protein contents. A tetraploid oat contains 23-30\% protein (Murphy, Sadanaga, Zillinsky, Terrell \& Smith, I968), and some sorghums contain I8-26\% (Johnson, Schmidt \& Mattern, I 968 ). Even if the promise in these discoveries is substantiated, and protein-rich cereals are bred that can grow in all parts of the world where cereal growing is traditional, other protein concentrates will still be needed.

In parts of the wet tropics, cereals do not ripen properly. It is hazardous to become wholly dependent on a single crop for diseases have a disquieting ability to change their virulence. And people want, and are wise to want, variety.

Even if we assume that there will soon be no frank hostility between different countries, it is unreasonable to assume that one group of countries will make itself permanently responsible for supplying protein to another. This means that the most useful contribution a prosperous country, with an efficient research organization, can make is to devise means whereby an ill-fed one can produce its own protein. A few countries may be able to exist, as we do in Britain, by importing protein and other foodstuffs, but it is not easy to see what most of the ill-fed parts of the world could export to pay for their imports. Not only should foods rich in protein be produced, in the countries where they are needed, they should be produced, in part at least, near the spot where they will be eaten. Special attention should therefore be given to methods for producing protein from local products for local consumption.

At present, the problem is most acute in densely populated tropical regions with prolonged, or even daily, wet periods. The assumption underlying much agricultural planning is that the ill-fed state of so much of the wet tropics is essentially an accident, which can be corrected by the more widespread adoption of conventional agricultural techniques. I assume, on the other hand, that we have not yet found out how to farm the wet tropics.

The most obvious method for increasing the protein supply is to grow more of those familiar foods that are rich in protein. Peas, beans and oilseeds are important in the ill-fed parts of the world for, unlike the traditional cereals, these seeds contain $25 \%$ or more of protein. Because of the risk that they will rot rather than ripen, they do not thrive in regions where it rains nearly every day, but, where the climate is suitable for them, they deserve very much more attention from plant breeders and agronomists than they are getting. Leafy vegetables and immature flowers cannot supply as much protein as the pulses because of the amount of fibre in them, but they could be eaten much more extensively than they are. Some contain $30 \%$ of protein (on the dry matter). Many leaf species, e.g. amaranth, beobab, drumstick and sweet potato, that are unfamiliar in the temperate zone, are still widely eaten, but their popularity is declining as a result of the preconceptions of visiting 'experts'. This is a trend that should be combatted: we should increase rather than diminish the number of food plants. In the wet tropics, green vegetables give as great a yield of protein as any other crop that is extensively grown: $400 \mathrm{~kg}$ of protein 
per hectare in 3 months is reported (FAO, 1964). The area devoted to market gardening is increasing and so is the attention that is given in India and elsewhere to school gardens. People have to be persuaded that green vegetables are more important than crops such as ockra and tomato, and work on the school garden must be made part of the normal curriculum and not a punishment.

The fibre in leaves limits the amount that can be eaten. Protein can be extracted from many different species (Pirie, 1956 , $1966,1969 a$ ) and, when extracted, is easy to make up into acceptable dishes (Byers, Green \& Pirie, 1965). Like many other food proteins, it is easily damaged by improper handling, e.g. over-heating during drying (Buchanan, 1969). When competently prepared its nutritional value in chickens and rats (Duckworth \& Woodham, I961; Woodham, 1965), rats (Henry \& Ford, 1965), pigs (Duckworth, Hepburn \& Woodham, 1961), infants (Waterlow, 1962) and children (Doraiswamy, Singh \& Daniel, 1969) is greater than that of other vegetable proteins though not so good as exceptional proteins such as milk and egg. Many years ago FAO baselessly asserted that leaf protein would be expensive to manufacture; the statement is repeated from time to time. Actual costs will not be known until large-scale production starts. A reasonable estimate (Pirie, 1969a) makes this protein cheaper than any other (apart from by-products) except for soya when that is grown in favourable climates. The yield at Rothamsted improves yearly and is now 2 tons (dry matter) per hectare (Pirie, $1969 b$ ); in India, with no cessation of growth in winter, it is 3 tons. So that systematic agronomic studies can be made in different countries, and with support from the International Biological Programme, we have made laboratory-scale extraction units (Davys \& Pirie, 1969; Davys, Pirie \& Street, 1969). These are already in use in India and Nigeria and more are being made so that agronomic research can be done in other countries.

Coconuts, like leaves, contain good-quality protein (Snyderman, Boyer \& Holt, 1961; Butterworth \& Fox, 1963; Rao, Ramanatham, Indira, Rao, Chandrasekhara, Carpenter \& Bhatia, 1967) accompanied by so much fibre that people cannot eat much. Rapid progress is being made in perfecting mechanical and enzymic (Ramamurti \& Johar, 1963; Chandrasekaran \& King, 1967) methods for separating protein from the fibrous mass. Coconuts and leaves have the outstanding advantages as protein sources that they flourish in the wet tropics and that the extraction procedures are simple enough to be feasible as a village industry. These proteins will be important by the end of the century; only lethargy, and the hostility of national and international organizations responsible for agricultural affairs, keep them from being important now.

The residues from expelling oil from soya, groundnut and cottonseed are the most abundant, unused or inadequately used sources of protein. Estimates of the amount of protein contained in these residues vary somewhat: a conservative one is ro $\mathrm{M}$ tons. Some oilseeds are now being handled with sufficient care to yield residues of edible quality. Soya flour is extensively used in human food, and foodstuffs based on groundnuts and cottonseed are coming into use in India and Central America. The Tropical Products Institute (Orr \& Adair, 1967) published a useful set of statistics on these products and surveyed some aspects of their production and use. 
Bressani, Elías \& Braham, (I966) give more information about cottonseed, and Bassir \& Loebel (1968) describe the successful use of soya in child nutrition.

Plant-breeding programmes are only slowly becoming attuned to the protein shortage. Varieties of maize, rice and wheat with enhanced protein content, and sometimes with protein of better quality as well, have been produced; there are also strains of cotton from which the harmful constituent, gossypol, has been partly or completely eliminated. If these new varieties yield as much, and are as resistant to diseases, as the old ones, they will contribute greatly to the world's protein resources. Soya, in suitable climates, can yield 2 tons of protein per hectare. Unfortunately the protein is accompanied by carbohydrate that is largely indigestible by people, and by substances that inhibit proteolytic enzymes. Hence the use of elaborate methods of fermentative pretreatment in those countries where the use of soya is traditional. No attention has been paid, so far, to breeding coconuts or leaf-crops in which protein is both abundant and readily extractable.

It is salutary to remember that the strains of maize that were hailed recently as a 'break through', because of their improved protein quality, had been lying unesteemed on the shelf for 30 years. And it is encouraging to find that the point now rates official attention. In a report to the UN Economic and Social Council in 1968 the Protein Advisory Group says: 'In agricultural planning attention should be given to the production of protein as well as total yield, since an increase in yield may often result in a decrease in protein content per unit of production. Attention should also be given to the quality of the protein in the crops produced'.

In most parts of the world people use animal products as protein concentrates when they can afford them. So long as animals are not fed on products that people could have eaten, or on products grown on land that could have produced food for people, this is an excellent arrangement; there are many agricultural by-products that would be wasted if not used as fodder and much land that is unsuitable for ploughing but on which cattle can graze. But the process of animal conversion is too inefficient to be tolerated in any region with a protein shortage, if it uses land to produce fodder rather than food. The issue is confused by lack of precision in terminology. It is now possible to get a pound of chicken from two pounds of feed: but what is measured is dry feed and wet chicken-including guts, neck, feet and other inedible parts. Furthermore, to achieve that conversion rate the chicken has to be fed largely on material that people could have eaten.

Domestic cattle will probably continue to be more productive than any other species (unless another species is subjected to a comparable amount of skilled selection) when kept on well-managed sward; that usually means on potentially arable land. Other species, and especially a mixture of species, may well fare better on the mixed vegetation on unmanaged land-one obvious reason for this is that, by grazing and browsing at different levels, more complete use would be made of the natural mixed vegetation. The whole subject of the merits of wild animals has been comprehensively reviewed recently (e.g. Maloiy, I965; Golley \& Buechner, I968), but properly controlled experiments, comparing the productivity of wild and domestic animals on similar terrain, are long overdue. 
In articles such as this it is traditional to stress the potentialities of fish. Some extravagant claims have been made. FAO estimates that the catch could not be more than trebled without depleting stocks. A great deal of effort is being put into research on the conversion of fish into tasteless powders with a long shelf-life. It is a pity greater effort is not put into improving the marketing, distribution and preservation of fish so that it could be eaten more extensively in a more natural state.

All the foods mentioned so far depend on current photosynthesis. A plant uses sunlight to convert carbon dioxide into products that are then used as food, as the raw material for processing into food, or as fodder. An increasing amount of interest is now being taken in the cultivation of yeasts and other micro-organisms on the products, in part, of past photosynthesis. 'In part' because, although the carbon that appears in the microbial mass comes from coal or oil, large amounts of oxygen are also needed and this is the product of current photosynthesis. The possible scale of production is enormous; the unwanted paraffin fraction of the oil now used would produce $20 \mathrm{M}$ tons of protein per year. Production could become even greater if limestone were used as the carbon source instead of fossil fuels. Ultimately microbial protein may become a very important human food. It does not seem likely to have a great immediate affect on the nutrition of those most in need because the techniques involved in cultivating the micro-organisms, and removing the fuel residues from them, are too sophisticated to be used in their countries. The techniques, and difficulties, of production from oil are discussed by Tannenbaum \& Mateles (I968) and by Llewelyn (1968); the potentialities of coal are discussed by Silverman, Gordon \& Wender $(\mathrm{r} 966 a, b)$. The enterprise that is being shown by the oil companies will direct attention to the potentialities of microbial protein; its most important immediate consequence will probably be that better use will be made of molasses and other existing agricultural by-products on which microorganisms could be grown.

I have made (Pirie, 1969a) a rough classification of the principal merits and demerits of the more important novel protein sources. It was obvious 25 years ago that there was a protein shortage, that it was likely to get worse, and that research would be needed to mitigate it. It is unfortunate that those in control of national and international research policies have shown so much prejudice and unawareness of the possibilities that this research is only now beginning on a serious scale. There is a danger that the various potential sources of protein will be regarded as alternatives rather than as complements. No single novel source of protein is likely to satisfy the impending need, partly because people prefer a mixed diet, and partly because climate and conditions vary. Near the shore of an underexploited sea or lake, fish deserve most attention. In regions with adequate spring rain followed by a hot summer with dry spells, no source of protein is likely to outyield soya and the other oilseeds. Where there is rain almost every day (about a fifth of the world's population lives in such a climate) coconuts and leaves are the pre-eminent protein sources. In industrialized communities with access to fossil fuels or agricultural wastes, part of the need will be met by centralized production of microbial protein.

The introduction of novelties calls for great skill, tact, sympathy and patience. 
Experience in the food industry shows that the success or failure of a new line cannot be predicted; it may depend on accident and chance association. There is little evidence from animal experiments, but Revusky \& Bedarf (1967) found that rats given a dose of X-rays, sufficient to cause mild malaise, when they were eating a novel food, took to the food less readily than the controls. People probably have an even greater tendency to make logical but unfounded correlations. McConnell (I968) describes a fascinating experiment in which sixty married students were, during several weeks, given beer, all from one batch, but put up in bottles carrying three different labels and with different apparent prices. They quickly built up strong preferences and only one, a woman, is recorded as having maintained throughout that all tasted the same. A moment's thought about the surprising textures, flavours and antecedents that are relished in different parts of the world shows that there are few, if any, intrinsically unacceptable potential foods.

I have discussed these issues at greater length elsewhere (Pirie, I969c). Only two more points need be made here. When it is difficult to get a desirable product accepted, it is essential to find out whether there is any factual basis for the reluctance. Factually and emotionally based oppositions are equally real-but different approaches are needed in combatting them. A common obstruction takes the form 'people will not change their habits'. The changes in food and agriculture in much of the world during the past half century show that this is nonsense. If the thesis is accepted that $20 \mathrm{M}$ tons more protein are needed now and that still more will be needed by the end of the century, change is inevitable. The fact that popularization of novelties may prove difficult is all the more reason for getting started on the job soon, and the fact that there are many random factors in acceptance is an argument for attempting the job in several different centres. Failure, like success, happens with one group of people, in one set of circumstances, at one time. There are conditions in which success is likely, and a few more successes would help enormously in overcoming inertia.

\section{REFERENCES}

Bassir, O. \& Loebel, W. (1968). West Afr. F. biol. Chem. r1, 70.

Bressani, R., Elías, L. G. \& Braham, E. (1966). Adv. Chem. Ser. no. 57, p. 75.

Brožek, J. (I962). Ann. N.Y. Acad. Sci. 93, 665 .

Buchanan, R. A. (1969). Br. F. Nutr. 23, 533.

Butterworth, M. H. \& Fox, H. C. (1963). Br. F. Nutr. 17, 445 .

Byers, M., Green, S. H. \& Pirie, N. W. (1965). Nutrition, Lond. 19, 63.

Chandrasekaran, A. \& King, K. W. (1967). भ. agric, Fd Chem. 15, $3 \circ 5$.

Chow, B. F. \& Blackwell, R. Q. (1968). Borden's Rev. Nutr. Res. 29, 25.

Creamer, B. (1967). Br. med. Bull. 23, 226.

Davys, M. N. G. \& Pirie, N. W. (1969). Biotech. Bioengng (In the Press.)

Davys, M. N. G., Pirie, N. W. \& Street, G. (1969). Biotech. Bioengng (In the Press.)

Doraiswamy, T. R., Singh, N. \& Daniel, V. A. (1969). Br. $¥$. Nutr. 23, 737.

Dubos, R. (1965). Man Adapting New Haven and London: Yale University Press.

Duckworth, J., Hepburn, W. R. \& Woodham, A. A. (1961). F. Sci. Fd Agric. 12, 16.

Duckworth, J. \& Woodham, A. A. (1961). F. Sci. Fd. Agric. 12, 5.

FAO (1964). The State of Food and Agriculture Rome: FAO.

FAO/WHO (1965). F.A.O. Nutr. Mtg Rep. Ser. no. 37.

Golley, F. B. \& Buechner, H. K. (I968). IBP Handbook, no. 7.

Henry, K. M. \& Ford, J. E. (1965). F. Sci. Fd Agric. 16, 425. 
Hofmann, R. R. (1968). Symp. zool. Soc. Lond. 21, 179.

Johnson, V. A., Schmidt, J. W. \& Mattern, P. J. (1968). Econ. Bot. 22, 16.

Lawes, J. B. \& Gilbert, J. H. (1852). Rep. Br. Ass. Adv. Sci. p. 323.

Lawes, J. B. \& Gilbert, J. H. (1866). Phil. Mag. (4th ser.) 32, 55.

Llewelyn, D. A. B. (I 968). Microbiology, p. 63. [P. Hepple, editor.] Inst. Petroleum.

McConnell, J. D. (I968). F. Marketing Res. 5, I3.

Maloiy, G. M. O. (1965). Nutr. Abstr. Rev. 35, 903 .

Murphy, H. C., Sadanaga, K., Zillinsky, F. J., Terrell, E. E. \& Smith, R. T. (1968). Science, N.Y. I59, 103.

Neale, G. (1967). Proc. R. Soc. Med. 6o, 1069.

Orr, E. \& Adair, D. (1967). The Production of Protein Foods and Concentrates From Oilseeds. Publ. G 31 of Tropical Products Institute, Ministry of Overseas Development, London.

Pirie, N. W. (1956). Proc. Nutr. Soc. 15, I54.

Pirie, N. W. (1966). Science, N.Y. r52, 1701 .

Pirie, N. W. (1969a). Proc. Nutr. Soc, 28, 85.

Pirie, N. W. (1969b). Ann. Rep. Rothamsted Exp. Stn p. I12.

Pirie, N. W. (r $969 c)$. Food Resources : Conventional and Novel. Penguin Books.

Ramamurti, K. \& Johar, D. S. (I963). Nature, Lond. r98, $48 \mathrm{I}$.

Rao, G. R., Ramanatham, G., Indira, K., Rao, U. S. B., Chandrasekhara, M. R., Carpenter, K. J. \& Bhatia, D. S. (1967). Indian F. exp. Biol. 5, I14.

Revusky, S. H. \& Bedarf, E. W. (1967). Science, N.Y. 155, 219.

Silverman, M. P., Gordon, J. N. \& Wender, I. (I966a). Adv. Chem. Series, no. 57, p. 269.

Silverman, M. P., Gordon, J. N. \& Wender, I. (1966b). Nature, Lond. 21 I, 735.

Snyderman, S. E., Boyer, A. \& Holt, L. E. (196I). Publs natn. Res. Coun., Wash. no. 843, p. 33 I.

Squires, B. T. (1966). Cent. Afr. F. Med. 12, 223.

Stevenson, J. A. F. (1946). Proc. Nutr. Soc. 4, 2 I2.

Stewart, R. J. C. \& Platt, B. S. (I968). Proc. Nutr. Soc. 27, 95.

Tannenbaum, S. R. \& Mateles, R. I. (I968). Science F. 4, no. 5, p. 87.

Waterlow, J. C. (1962). Br. F. Nutr. 16, 53 I.

Woodham, A. A. (1965). Proc. Nutr. Soc. 24, xxiv. 